\title{
The Post-Communist Evolution and Constitutional-Legal Engineering of the Model of Democracy in North Macedonia (1990-2001)
}

\section{Driton Kuqi}

\section{Abstract}

The first decade after the breakup of Yugoslavia, was crucial for the North Macedonia state and its citizens. The constitution of the new, independent state was not an easy process and it did not pass peacefully and with no problems. The complex social process and relations have initiated the need for amendments to the Constitution, which, since its adoption in 1991 until today, has been changed 32 times in order to adapt to the new emerging situation and to give a constitutional and legal response to the real challenges. Of course, proper changes also occurred in the political system itself, as a result of numerous factors, which more or less influenced its character and shape.

Keywords: democracy, consociational democracy, constitutional order

\section{Introduction}

From the moment of independence, the electoral model in the Republic of North Macedonia, as an important element of the electoral system in wider sense of the word, has undergone numerous transformations: from a majority principle election modelin two rounds, to a proportional representation with closed lists. In the first parliamentary elections in 1990 and the second in 1994, the allocation of mandates was carried out by applying the majority principle election modelin two rounds, within unanimous electoral units. The Law on the Election of Members of Parliament in the Parliament of the Republic of North Macedonia since 1998 abandoned the majority electoral model and replaced it with the combined (mixed) electoral model, according to which 85 seats were allocated on the basis of the majority electoral model with a relative majority, and 35 MP seats, on the proportional model. In the 2001 elections held after the armed conflict and after the adoption of the Framework Agreement and the constitutional amendments, as well as all subsequent elections, the proportional election model is applied.

\section{About the democracy}

The democracy belongs to the ranks of the great politically-legal, ethicallyphilosophical and sociological phenomena that have always attracted the attention of 
scientists from almost all socially humanitarian areas (Bajaldziev, 2009) Each one analyzes and explains democracy through its own lens. The term democracy is one of the most widely used concepts in political science and everyday life, and it is also a target, the use of which leads to a great deal of confusion, since it pulls away when trying to define it (Klimovski, Karakamisheva, Desoska, 2010) It is therefore no coincidence that in determining this concept there is almost always striving to one or other essential content or a certain characteristic that, as the whole, completesits meaning.Most simply defined as the "rule by the people," this form of social order had been subject to different, far apart conceptions. Starting from a "bad and undesirable form of government," for what Greek philosophers Plato and Aristotle considered, through the concept of Jean Jacques Rousseau and Montesquieu that democracy is "a common good," we come to today's "era of democracy" for whichspeaks the fact that from 195 states, 125 declare themselves as democracies.

During its more than 2,500-year history, democracy has been constantly renewed and developed through various models of institutional implementation. Democracy is not invented at once, like a steam engine, but it has been created multiple times, in different societies (Dahl, 1998). But the widespread acceptance of democracy as an appropriate form of organization of political life is one hundred and fifty years old. Namely, the term "democracy" in its modern sense began to be used in the nineteenth century, signifying a system of representative democracy, in which representatives were elected to fair and free elections. Historically, through wide variety differences, today we can conclude that modern democracy rests on several values: participation as a broader concept that not only has strong political implications, but also social and economic; majority rule and minority rights, which points to the fact that while democracy is by definition the rule of the majority, it must also take into account the rights of minority groups; rule of law and fair trial, which ensures an autonomous legal order, a restriction of the powers of public authorities and the provision of fair access to an independent and fair judiciary; a commitment to human rights, whose respect, protection and fulfillment must be secured by a democratic state; political pluralism that can provide sufficiently flexible structures to adapt to changes, but which still remain a stable basis for democratic governance; free and fair elections, as the most basic and unique characteristic of democracy, through which every citizen can express his will for change, i.e. compliance with current policies and participating in the ongoing process of assessment; and the separation of powers between legislative, executive and judicial bodies that function independently, but who have responsibility for each other and for the people.

As a system of government, democracy is still the target of many criticisms to this day. Most of them move in the same direction - not all citizens can be equally educated and informed about the political life in the country, so it would not be beneficial for them to make important decisions. One of the disadvantages is connected with the achievement of equality, the possibility of self-destruction as a result of its openness, as well as the problem with the majority government, more precisely if there are 
certain limits that the majority cannot overstep and rights that it cannot take away from minority by outvoting. The Italian philosophers Wilfredo Pareto and Gaetano Mosca, however, claim that democracy is just one facade that serves the political elites to mask the reality.

However, the weaknesses of democracy are incomparably smaller than those of undemocratic system of government, giving it a huge advantage over others, because democracy is above all a system over which citizens have control. Former British Prime Minister Winston Churchill on Democracy will say: "Democracy is the worst form of government, except for all the others." This well-known quote brings us to an important conclusion: the perfect democracy does not exist, but in spite of that, it is the most successful system of government.

Behavior in accordance with the opinion of the majority, however, is not a central point of interest for the pluralist democracy. Namely, according to this model, democracy exists when many organization acting separately from the government are putting pressure on it, confronting it with its own interests and causing its reaction (Dahl, 1982). Unlike the majority model, according to the supporters of pluralist democracy, instead of a center of sovereign power, it is necessary to have more power centers, none of which is and cannot be sovereign. The pluralist model seeks to limit the actions of the majority, so that the interest groups come to the fore. According to US political scientist Dahl, this is a model where decision-making does not come from a single political center that is in the role of a monopoly, but such power is distributed both vertically and horizontally at a number of different levels of decision-making. What ensures the well-functioning of this model is the consensus for the basic liberal values in the political life. On the other hand, the majoritarian democracy is based on electoral mechanisms that turn the power of the majority to make the political decisions. In this model of democracy, the wider public (rather than interest groups) control the actions of the government.

The key principle of organizing the rule of democratic systems is the division of power into legislative, executive and judicial. The consistency with which the government is divided, as well as the forms of their mutual control and cooperation, give the answer to the question of what kind of institutional model of the political system is concerned. The relationship between legislative and executive power is essential for any political system. This relationship is determined by the constitutional position of institutions, but also by political and other external factors. The constitution of a state is the one that determines the horizontal relation between the legislature and the executive power, its powers and duties, as well as the possibilities for mutual influence.

When one system is said to be based on the principle of separation of powers, it means that the relations among the holders of state power are characterized by organizational and functional independence (Klimovski, Deskoska, Karakamisheva, 2009). All forms of organization of state power occurred on an empirical procedure. In time, the parliamentary system in England was shaped, followed by the 
presidential system in the United States, while the parliamentary system had its first constitutional presence in Switzerland. Over time, there was some convergence of the systems to their approximation, resulting in mixed systems (Jovicic, 1992).

The presidential system is a system of government based on the principle of strict separation of state power and the principle of "checks and balances" between the legislative, the executive and the judicial power. This system finds its original form in the United States, which today may be the only successful presidential system of governance.For the parliamentary system, the existence of a flexible division of power is characteristic, which is expressed by equality, cooperation and mutual influence between the legislative and the executive power. This system was created in England, and consistency in its application is observed in both Japan and Italy. Today it appears in many varieties and shapes in Belgium, the Netherlands, Canada, India, Germany and other countries. The parliamentary system is built on the unity of power, where the Parliament is the sole holder of the legislative process, with no other state body having the right to abolish or annul the laws and the highest acts. The Assembly elects, i.e. appoints the executive bodies that are then accountable to it.This system of government exists today in Switzerland. Mixed systems are characterized by combined elements of the presidential and parliamentary system. The most important feature in this system is the position of the head of state as the basic institution of the system. In addition, there is a flexible division of power and political responsibility of the government in the parliament. The mixed system has its roots in France, and its example was followed by Portugal, Russia, Poland, Ukraine and other Eastern European countries.

\section{Constitutional legal framework of the model of democracy in the Republic of North Macedonia}

On November 17, 1991, the Constitution of the Republic of North Macedonia, which was preceded by the Declaration of a Sovereign and Independent State, was adopted. The precursor of the Constitution of the independent Republic of Macedonia were the constitutional amendments adopted in August 1990, which created a legal framework for starting the transition of the state from socialism to democracy and from a federal state of SFRY to an independent state. This Constitution, according to its conception, is among the liberal democratic constitutions that have already been adopted during the nineteenth century and, with certain changes, have remained ruling even today in the democratic countries (Klimovski, Deskoska, Karakamisheva, 2009). In the philosophy of this Constitution, central value was the liberal democracy with a parliamentary form. At the same time, the Preamble of the Constitution starts from the historical fact and the historical and legal continuity of the Macedonian state as a national state of the Macedonian people, which ensures full civic equality and permanent coexistence of the Macedonian people with Albanians, Turks, Vlachs, Roma people and other nationalities that live in the Republic of Macedonia. 
In the period after becoming independent, the Republic of Macedonia faced many challenges as a new independent state that was created on the basis of the right to self-determination after the break-up of the SFR Yugoslavia. After the proclamation of independence, the country began moving towards the development of a parliamentary democracy, where the freedom of political association was guaranteed for the first time, that is, the formation of several political parties as subjects in the election contest. The Assembly became unicameral, and instead of the collective presidency of the Republic of Macedonia, the position President of the Republic was introduced. The Executive Council became a government, and the secretariats were renamed to ministries. This precisely was the establishment of the elements of the next parliamentary system. Set on the basis of the already well-built democracies, the Macedonian Constitution introduced a system of "checks and balances" with the separation of power into executive, legislative and judicial power (Chokreski, 1998).

The relatively short lived experience of Macedonian parliamentarism and democracy once again proves that the actual power and relations of the Macedonian institutions depend not only and mostly on the constitutional norms. During most of President KiroGligorov's mandate, the system of governance de facto functioned as presidential (Siljanovska, 2010). The strong personality and social democratic parliamentary majority in the period 1992-1998 enabled Gligorov to play the leading role in making important decisions.

With the Constitution of 1991, the Republic of North Macedonia was defined as a sovereign, independent, democratic and social state. The fundamental values of the constitutional order were exposed through 11 basic principles, with a democratic sign that "in the Republic of Macedonia, everything that is not prohibited by the Constitution is permitted". According to it, the socio-economic and political system is based on the principle of the rule of law, human freedoms and rights, the separation of power, the market economy and other fundamental values of the modern democratic society. The adoption of this Constitution marked the beginning of the construction of a new social and political system, as well as a new political and economic strategy for the development of the state. But did this Constitution pass the test of time? During its existence of 25 years, the Constitution was amended on seven occasions, and it currently has 32 amendments. Under the pressure of the Republic of Greece, as well as the pretensions for membership in the United Nations, in 1992, two amendments were adopted that referred to the fact that Macedonia has no territorial pretensions towards other countries and that it will not interfere with the internal affairs of other countries. As part of the announced battle for dealing with organized crime and corruption, in 1998, the detentionof 90 days increased to six months.

The most dominant and dramatic were the changes in 2001, when the principles and rules of the Framework Agreement were embedded. Namely, there was a change of 15 Articles that related mostly to the issues of using languages and alphabets, cultivating their own ethnic identity, the use of symbols, the mechanisms of political 
decision-making in the selection of important state functions and bodies, and the formation of separate parliamentary bodies. Primarily, an amendment to the constitutional preamble was made, which established the multiethnic character of the state. The amendment of 2004 provided constitutional protection of the freedom and inviolability of letters and all other forms of communication, and one could deviate from this right only by a court decision. As a result of the efforts for Euro-Atlantic integration, reforms in the judiciary were carried out in 2005; i.e. the definition of courts, the election and dismissal of judges, the establishment of the judicial council and the guarantee of the right of appeal. In 2009, the presidential electoral threshold was reduced from $50 \%$ to $40 \%$, and with the amendments in 2011 was provided the possibility of extradition of Macedonian citizen on the basis of a ratified international agreement, with a court decision.

\subsection{The political system in the Republic of Macedonia 1991 - 2001}

The very independence of the Republic of Macedonia and the period that occurred during and after forming the first government, marked the development of new political processes, which from the very beginning were accompanied by intense crises in the political dialogue in the country. Although some analysts stressed out that transition countries are always confronted with the danger of radical nationalism and ethnic conflicts, others optimistically argued that democracy could be a matter of agreement (Siljanovska, 2010). Both sides were right - while the other Yugoslav republics were military fields, Macedonia remained an "oasis of peace". Until the armed conflict in 2001.

After the introduction of the political pluralism with the constitutional changes of 1989 (Official Gazette of SRM, no.16/89), which enabled the formation of political parties, in 1990 the Macedonian voters had the opportunity to vote in multi-party elections for the first time. At the same time, this was the first free multi-party election held during the same year in all six republics of the Socialist Federal Republic of Yugoslavia (SFRY). The elections were held according to the majority voting system in two rounds, with the territory of the Republic divided into 120 electoral units. This election was characterized by the nomination on the broadest base, small electoral units, individual elections and the distribution of mandates by applying the majority system with absolute and relative majority of votes. Although the process of political pluralization in the Republic of Macedonia was slow, however, in the middle of 1990, the "captured political spirit" seemed to have left the decadal constraints and views towards the modern development (Mojanovski, 2010).

The finding and functioning of several political parties is one of the fundamental characteristics of any democratic political system. Through an electoral competition and mobilizing the voters behind a certain vision for the society, the parties are offering the citizens a diverse choice and opportunity to manage and form the future of the state. There may be no democracy in the parties, but there can be no democracy without political parties (Hoffmeister, Graben, 2008) 
The elections that took place in November and December 1990 have passed in such circumstances where the dissolution of the Federation was already foreseen, which in the elections in most of the republics, resulted in the victory of the newly-formed national parties over the parties that emerged from the republican branches of the Communist Party of Yugoslavia. The first elections were attended by 18 political parties and 43 independent candidates. The parties in some of the electoral units participated individually, but in others they formed mutual coalitions, with candidates running for joint candidates.

The first elections held in November 1990 had the following results:

\begin{tabular}{|l|l|}
\hline Party & Seats in Parliament \\
\hline VMRO-DPMNE & 38 \\
\hline League of Communists of Macedonia (SKM-PDP) & 31 \\
\hline Party for Democratic Prosperity (PDP) & 17 \\
\hline Union of Reform Forces (SRSM) & 11 \\
\hline Socialist Party of Macedonia (SPM) & 4 \\
\hline Party of the Yugoslavs & 2 \\
\hline People's Democratic Party & 1 \\
\hline
\end{tabular}

Although in these elections the majority was won by VMRO-DPMNE, it was not enough to form a government. Refusing to join a coalition, this party did not win enough seats in Parliament. In fact, no party could form a government on its own, which resulted in the formation of a caretaker government on March 21,1991, headed by the member of the Macedonian Academy of Sciences and Arts (MANU), Nikola Kljusev, who suggested experts for ministerial seats. This government counted 22 ministers, proposed by several parties, comprising university professors and intellectuals. In its mandate of the more important acts - the Constitution was adopted, the independence referendum was organized and the Army of the Republic of Macedonia (ARM) was formed. Although the referendum was successful, it was mainly boycotted by the Albanian population. The same thing happened with the Constitution, which was adopted on November 17, the same year. At all stages of the adoption of the Constitution, Albanians participated in debates in the Parliament, but also in public debates. The discussions of the Albanian deputies concerned the state to be constituted as a multiethnic state, in which the Albanians would be constitutive nation. All amendments to Albanian MPs were rejected by the majority in Parliament. That was the reason why Albanian MPs did not vote on the Constitution and, as a sign of revolt, even left the Parliament during the voting.

Due to disagreements between the parties, the mandate of the caretaker government ended on July 7, 1992, when it lost the confidence vote, and this event was followed by one of the biggest constitutional gaps in the constitutional history of the Republic of Macedonia (Markovis, Popovic, 2015) After Ljubco Georgievski and Petar Goshev rejected the mandate to form a new government, Branko Crvenkovski, as the 
prevailing leader of the SKM-PDP, formed the second government, which was political this time.

The period that followed also did not pass without some controversy. The political organization created parties on ethnic grounds that prevented the development of the civic volume and the feeling of a political community. Although in writing there were no formal requests for coalitions among major political parties, practice showed that they became a tradition in Macedonian politics. All of the governments, regardless of the election system and the election results, have made coalitions with some of the Albanian parties, mostly those with the largest support among the Albanian community. Such coalitions were necessary, not only from a mathematical point of view, but also from a political one. Macedonian and Albanian political elites were forced to cooperate due to external pressure (Berghund, Ekman, Deegan-Krause, Knutsen, 2013). However, the parties have calculated that this is of mutual benefit, and such coalitions have become a practice. Thus, in the period between 1992-1994 and 1994-1998, the Social Democratic Union (SDSM) elected the Albanian Party for Democratic Prosperity (PDP) as its coalition partner. This practice of involving the Albanian parties as coalition partners has become widely accepted in the political life of Macedonia. This is also evidenced by the fact that the conservative Christian Democratic Party VMRO-DPMNE, which has won the majority of the votes in 1998, decided on a coalition with the Albanian Democratic Party of Albanians (DPA).

\begin{tabular}{|l|l|l|l|}
\hline Time period & Macedonian party & Albanian party & $\begin{array}{l}\text { Number of Albanian } \\
\text { portfolios }\end{array}$ \\
\hline $1992-1998$ & SDSM & PPD & $4-6$ \\
\hline $1998-2002$ & VMRO-DPMNE & PDSH & $6-8$ \\
\hline $2002-2006$ & SDSM & BDI & $5-7$ \\
\hline $2006-2008$ & VMRO-DPMNE & PDSH & 5 \\
\hline $2008-2011$ & VMRO-DPMNE & BDI & 8 \\
\hline $\begin{array}{l}2011- \\
\text { present }\end{array}$ & VMRO-DPMNE & BDI & 9 \\
\hline
\end{tabular}

Source: S. Berglund, J. Ekman, K. Deegan-Krause, T. Knutsen, The Handbook of Political Change in Eastern Europe, Third Edition, 2013, page 629

Although the interethnic coalitions in the government have already been practiced, it can be noted that in the period from 1990 to 2001, there was never an Albanian education minister in the government cabinet. The Ministries of Education, Internal Affairs and Defense were considered to be too sensitive areas to be assigned to an Albanian party (Koneska, 2012).

1992 started with amendments and supplements to the Constitution of the Republic of Macedonia, according to which it "has no territorial pretensions towards neighboring countries" and that "the border may be changed only in accordance with the Constitution", with respect for "the principle of voluntariness and in accordance with generally accepted international norms", and that "it will not interfere with the sovereign rights of other states and in their internal affairs." 
Internally, during 1993, particular attention was paid to the usage of the assets of parliamentary democracy, but also to the usage of forms of public demonstration and rally. Namely, during this period the opposition often boycotted the Assembly meetings. Regarding the political pluralism, it continued with the process of creating new political subjects. Thus, during this year, nine new political parties were formed.

1994 was marked with several important events for the Republic of Macedonia. Direct elections for president and MPs in the Assembly were conducted, and a census of population was conducted, backed and supervised by the international community. The presidential elections passed with six candidates on the electoral list. According to the Constitution, a person who, at the Election Day, is at least 40 years of age and is a resident of the Republic of Macedonia for at least ten years in the last fifteen years can be elected for president. The presidential elections were held in one election round, with the candidate Kiro Gligorov winning the required majority, or $52.44 \%$ of the votes. In the middle of this year, the first Law on Political Parties was adopted, which defines the manner, conditions and procedure for establishment, registration and cessation of political parties. After leaving the Yugoslav political monopoly, the establishment of many new political parties continued in the Republic of Macedonia. However, although the political pluralism is closely related to the democratic system of a state, it is not excluded that it acts counterproductively, that is, it has the so-called "effect of the supermarket" (Mojanoski, 2009). This means that of the multitude of offers, especially when it comes to similar or identical program options, the voter cannot realize the true one. Interestingly enough about the parliamentary elections in this year, is that many parties announced their participation through electoral coalitions. This time, the coalition Union of Macedonia, led by SDSM, has won. The opposition, VMRO-DPMNE and the Democratic Party, boycotted the second election round and claimed that there were serious violations in the election process. Such abstention of political parties of the electoral procedure undoubtedly influenced the final schedule in the structure of parliament, but also in the constitution of a strong democratic institution of parliamentary democracy - the opposition (Mojanoski, 2009).

Although the coalition Union of Macedonia provided a stable government by winning the majority, the absence of the opposition influenced the creation of a "party's monopoly". Namely, the executive power often put new legislative projects as a matter of decision-making, without first being well processed.

The trade embargo from Greece was an additional reason why the work of the Parliament had to be efficient. During this period, the work of the Government was dominating. This was perceived not only by the manifestation of power, but also by not accepting criticism from political opponents. This will be a serious handicap for the democracy in Macedonia and a step backwards from the previous parliamentary composition. However, the events began to occur differently in 1995, following the failed attempted assassination against the President Kiro Gligorov, which would have 
been a blow to Macedonia as an independent state. In this and the following years, the trend of creating new political parties continued. But it is important to note that these were the result of internal divisions of the already existing political subjects. An important time of this year is also the adoption of the Law on Local Self-Government. Following the deep centralized power of the Yugoslav system, the Republic of Macedonia realized the need to allow municipalities greater self-reliance in the governance. However, although with this law a step forward towards the transfer of power and authorizations was made, it did not define clearly the functions and responsibilities of the municipalities. In particular, this law did not make a clear distinction of the powers between the mayor and the municipal council, nor did it clearly define the issues related to municipal ownership and structure.

The year of 1996 was focused on the local elections for which the first law was passed. These elections were the first opportunity to face the two largest political forces in the country with voters. Therefore, they were seen as a test that would measure the relationship between the powers of the parties. Winning the city of Skopje and many other important municipalities, the opposition was declared as winner. The parliamentary elections in 1998 ended with a landslide victory for VMRO-DPMNE. This time, a new election model was introduced, according to which political parties that had the highest number of votes in the first round, enter the second one. These elections are significant because they have been the most real indicator of the segmentation of the political body in the Republic of Macedonia. This shows that it is grouped around four powerful political structures, VMRO-DPMNE, SDSM, DA and the coalition of the political parties of the Albanians in the Republic of Macedonia. If the elections of 1990 were elections for political promotion, the 1994 elections were elections for political stabilization, and these elections were the elections for the political profile of both the main political subjects and personal solutions (Mojanovski, 2009).

The presidential elections in 1999 were the second presidential elections in the independent Republic of Macedonia. The second election round is remembered for many irregularities, due to which the State Election Commission and the Supreme Court annulled the results in about 230 electoral units and ordered revote. This election was won by the VMRO-DPMNE's candidate, Boris Trajkovski. With these events, it can be said that Macedonia did not pass the test for peaceful and democratic elections. The OSCE observation mission noticed stuffing ballot boxes and multiple voting at several polling stations, and SDSM did not accept the newly elected president, referring to the irregularities on the Election Day. These elections confirmed the need to upgrade the electoral system, as well as to strengthen the trust between the political subjects and the citizens that participated in the election process. The end of the millennium marked many scandals, incidents and protests. The Parliament continued to have a central position, where the opposition played a constructive role. Shortly before the local elections, new political subjects were created. 
Generally speaking, the newly established constitutions of the former Yugoslav states took over the liberal democracy by establishing the concept of rule of law, civil rights and freedoms, political pluralism, free and democratic elections, free market, and respect for international law (Siljanovska, 2012). The years of independence were filled with intense parliamentary, but also non-parliamentary activity. The first decade was crucial for the Republic of Macedonia and its people. The process of independence and international recognition has begun, and in parallel, political pluralization and democratization of the Macedonian society took place. The pluralization contributed to the development of a rich political life, and on the political scene there were (out of) institutional forms, and the affirmation of the principles of parliamentary democracy and the power of dialogue became apparent. However, the Macedonian policy framework during the 1990s was contradictory. Although the Constitution of 1991 was once welcomed by the international observers as the first democratic-liberal constitution, it contained many flaws that later resulted in serious political turbulence. Such problems could have been foreseen in the process of its adoption, when the voting was boycotted by Albanian MPs. In practice, there have been serious violations of personal rights and really there was not any basis for the realization of the constitutional concept that protects them. Introduced overnight, parliamentarism as such was simply taken over by the Western states and incorporated into the Macedonian society, without any conditions for political dialogue and culture to be previously created. The Constitution, as well as the views of the most of the majority political parties, contributed to the "possession" of the state by the majority. Based on the practice of existence of nations and republics during the communist Yugoslavia, as well as the current fears that the neighbors will reach for the name and identity, all this contributed to the strengthening of the relation to property towards the state (Holliday, 2005). The constitutional and political order of the Republic of Macedonia in the period until 2001 had flaws in a formal, legal, institutional and functional sense. But, objectively speaking, it was a remarkably difficult period for a young and weak country in the middle of a complicated regional and international constellation (Vankovska, 2014)

\section{Conclusion}

The political system in the Republic of Macedonia, both from a normative point of view and from a realistic point of view, is a result of the mutual influence of several factors that determine its essence. At different periods of time, these factors played greater or lesser role, but the final result was a reflection of their overall impact. The first Macedonian Constitution practically adopted a radical systemic change as a result of the changed international and domestic social and political environment. The need for creating a new constitutional framework also appeared on the Macedonian ground, due to the transition from socialist one-party systems to democracy. The Constitution has undergone many changes in the form of numerous amendments that followed the transformation of the modern Macedonian state. The 2001 armed conflict resulted in the creation of a new relation of relationships in the Macedonian 
society in which the multiethnicity and the civic concept require a compromise that is most easily achieved by application of the most characteristic elements of the model of consociational democracy.The construction of power took place through elections, but the electoral model changed several times, from the majority, through a combined, and to a proportional one. This consensus characteristic was aimed at reflecting the ethnic and religious diversity of the Macedonian society.The flexible separation of powers as a feature of the parliamentary system can be seen in the mutual control of the three powers. Thus, the Assembly controls the executive power through the parliamentary questions, the interpellation, the vote of no-confidence of the Government, the election and dismissal of the President and members of the Government, the right to ask the President of the Republic for an opinion on issues within his jurisdiction; as well as through the right to raise an impeachment for the President of the Republic in case of violation of the Constitution and laws. The Assembly affects the judiciary mainly through the adoption of the Law on the Courts, which determines the type and number of courts, further by determining the court budget, through the election of a public prosecutor and the election of three out of fifteen members of the Judicial Council. The Government enters the legislative branch by proposing the budget, proposing laws, giving a mandatory opinion on draft bills, participating in the work of the Assembly, and the right to request a session. Whereas the President influences the legislative power through the suspensive veto power of laws that are adopted with a relative or absolute majority, as well as the appointment and dismissal of the Government and the appointment and dismissal of officials during military and state of emergency.From this we can conclude that the Macedonian system is a hybrid model in which the elements of parliamentary and consociational democracy are combined. Leaving liberal democracy, the Macedonian system of regulation was moving towards a power-sharing model, which, in postconflict societies, is supported, above all, by the international community as an optimal solution to the demands for secession and the right to self-determination.

\section{Literature}

[1] B. Vankovska, Political System of the Republic of Macedonia, Skopje, 2014

[2] C. Koneska, Vetoes, Ethnic Bidding, Decentralization: Post-Conflict Education in Macedonia, Journal on Ethnopolitics and Minority Issues in Europe, Vol. 11, No 4, 2012

[3] C. Mojanoski, Chronicle of the Macedonian Democracy, Skopje, 2009

[4] D. Bayaldiev, Introduction to Law, Skopje, 2009

[5] Division of power and implementation of the Ohrid Framework Agreement, Friedrich Ebert Foundation, Skopje, 2008

[6] Freedom In The World 2015, Discarding Democracy: Return to the Iron Fist

[7] Graham Holliday, "From Ethnic Privileging to Power-Sharing: Ethnic Dominance and Democracy in Macedonia" Sammy Smooha, PriitJärve (eds.), The Fate of Ethnic Democracy in Post-Communist Europe.. 
[8] Handbook for parliamentary elections in the Republic of Macedonia, Konrad Adenauer Stiftung, Institute for Democracy, 2014

[9] M. Jovicic, Parliamentary System vs. Presidential and Parliamentary System, Archive for Legal and Social Sciences, Belgrade, 1992

[10] N. Markovic, M. Popovic, Political Dialogue, Konrad Adenauer Stiftung, Institute for Democracy

[11] R. Dahl, Dilemmas of Pluralist Democracy, New Haven, Yale University Press, 1982

[12] R. Dahl, On Democracy, Yale University Press, London, 1998

[13] S. Berglund, J. Ekman, K. Deegan-Krause, T. Knutsen, The Handbook of Political Change in Eastern Europe, Third Edition, 2013

[14] S. Klimovski, R. Desoska, T. Karakamisheva, Constitutional Law, Skopje, 2009

[15] S. Klimovski, T. Karakamisheva, R. Desoska, Political System, Skopje 2010

[16] T. Chokrevski, Redefinition of the Function of Law in Transition Countries: The Case of the Republic of Macedonia, Balkan Forum, (2), 1996

[17] The former Yugoslav Republic of Macedonia, Presidential elections 31 October and 14 November 1999, Office for Democratic Institutions and Human Rights

[18] V. Hoffmeister, K. Graben, Functioning and Organization in Democratic Societies, Konrad Adenauer Stiftung, Institute for Democracy 